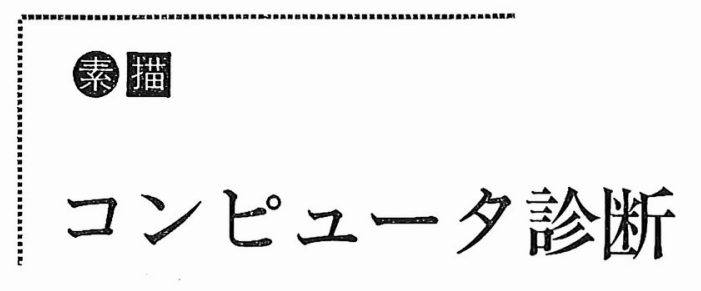

\title{
三宅浩之 関東逓信病院附属医用情報研究所
}

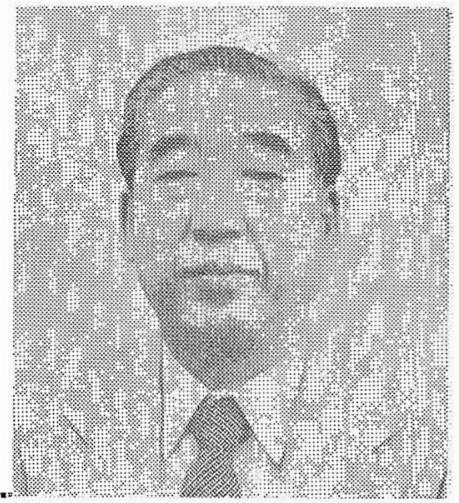

診断といら言葉は医療の中で最もよく使われている ようである.診には古来いわれるように視診, 問彰, 触診, 聴診などが含まれている、最近では，このほか に臨床検査という診断の補助手段がいろいると開発さ れて実用に供されて特り, 検查が䛦断確定の中心的役 割を果たすことも多くなってきた.このためもあって 個人の診断・治療に必要なあるいは利用できるデータ は增大の一途である. 一方, 大量データを能率よく高 速に処理することを目的とする装置としてコンピュー タシステムがある.そこで, 医療診断へのコンピュー タ利用という着想が生まれる。

一方，診断の根拠となる個々のデータを所見という が，患者を猃て所見を得る基本の見るといら機能は， 現在のところ人間のもつきわめて偉大な能力であっ て，その機能を機械またはコンピュータで置き換える ことにはまだ成功していないもちろん，人間の見る といら能力を增強して医療診断に利用する手段として は, 䡩微鏡, 内視鏡などの光学器械をはじめとして, 電子機器ではX線， $\gamma$ 線，超音波，NMR などによる 人体の透視や物質の分布, さらにコンピュータの高速 計算処理と図形処理を利用したコンピュータ断層撮影 に発展しこれまで人間の眼では見ることのできなか った脳内や体内の病変を図形として表示して診断精度 を飛躍的に向上させるのに成功している.さらに，私 ぞもの病院では人工知能の応用として, 守門医師の医 学常識の範囲の基本的な判断論理をコンピニータに与 えて患者情報の整理を行ない医師の診断作業を助ける ことを目的とする DOCTORS と呼ぶシステムの開発 に取り組んでいる.

では, コンピュータは人間の診といら能力にどれだ け近づいてくることができるだろらか。自発的にデー タを取り込む目・耳・手などをむたず，また，数多く
の経験を自然に蓄積し利用することのできる脳ももっ ていないといら前提でコンピュータを見た場合, 人間; にできることのなかで明らかにコンピュータが優れて いるとい光るのは何だろらか。経験を積んだ医師の一 見簡単な動作の上らに見える晾断洷る過程を助ける ようなコンピュータに適した作業は何だろらか.人は 生をれて 3 年もす机ぼ特別に教兄なくとも, 両親と他. 人の顔や声を見分けることができるようになる. 自然 に覚えるのだというが自然とは何か，その機構の解明: は脳の構造主体である神経網の分子レベルでの機能を 探ることで一歩ずつ進められてゆくことになろう.

現在の段階では，私はなだ診断をコンピュータに任 せた医療が可能であるという結論には達していない。 医者が日常行なっている診断といら行為の複雑さを分 析して、その一部であれ,コンピュータを使うことにメ リットのある分野を探し出すことが診断へのコンピュ 一タの利用の研究である. 医療に掓る診断治療の主 導権は人間の経験の蓄䅡に基づく思考と判断にあり， 将来とも人間である园師が患者から得ることでがきる 情報が診断の中心でありコンピュータはその作業を能: 率よく助けるものとして存在し続けるにちがいない。

最近, 第 5 世代コンピュータ, 知能コンピュータな どの話題が多くなり, 将来の可能性として眼耳口をも つコンピュータの実現が議論されるようになってきた が, ある学者が将来の人工知能の可能性として述べた 言葉として,「総合的な思考能力とい5点で人間と同 等の知能コンピュータが人間と共存する可能性は将来 ともありえないだろう、人間の能力にはるかに及ばな いか，はるか超えるかのいずれかである，そして人 間を超劣るようになったとさ人間は存在価値を失って 絶滅してしまうであろう」といっていることを紹介し てこの小文の結びとしよう.

\footnotetext{
Hiroshi Miyake, NTT 関東逓信病院 (141 東京都品川区東五反田 5-9-22) 附属医用情報研究所 電子応用医学研究部 長. 医博

〈略歴> 昭和 33 年東京大学医学部卒, 40 年東京大学医学系大学院第 3 臨床医学専攻課程修了. 日本脳神経外科学会認 定医. 41 年関東派信病院脳神経外科部長心得, 47 年より現職。
} 